\title{
Døde mænd og syge kvinder Køn, alder og
ulighed i sundhed
}

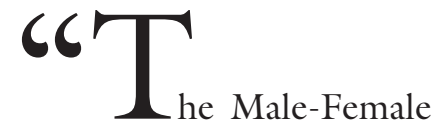

Health Paradox" er den internationale betegnelse for forholdet mellem ældre mænds og kvinders gennemsnitlige levealder og sygelighed. I mange lande dør mænd tidligere end kvinder (Christensen og Juel 2009), mens kvinderne har langt flere sygdomme i alderdommen, både genkendelige, accepterede diagnoser og mere diffuse lidelser, som er svære at leve med, svære eller umulige at behandle og mere vanskelige at få omverdens forståelse for. Ved fattigdom er der nogenlunde lige levetid mellem kønnene, men i velfærdssamfund øges kønsforskellen (Bakketeig og Schei 2007).

Der er generel interesse for at udligne forskelle i sundhedsstatus mellem forskellige befolkningsgrupper. Ikke desto mindre ser det ud til, at sundhedsforskning, sundhedspolitik og sundhedsformidling i Danmark i de senere år har etableret et fokus på køn, der underbygger og skaber uligheder i forhold til både køn, sundhed og alder. I denne tekst vil jeg lægge op til debat ved at 
give eksempler på, hvordan dette fokus har været rettet især mod mænds sundhed, men ikke mod kvinders - og navnlig ikke æaldre kvinder.

Som dokumentation anvender jeg dels medicinsk litteratur om kønsforskelle og levetid, dels rapporter og policy- dokumenter, som representerer dansk sundhedspolitik, offentlige og private sundhedskampagner, fx Sundhedsstyrelsens hjemmeside ${ }^{1}$ og hjemmesiden Selskab for Mands Sundhed. ${ }^{2}$ Der er desuden hentet diverse mediemateriale fra dagblade om emnet samt andre udvalgte empiriske eksempler; nogle af dem er erfaringer, jeg selv har gjort mig undervejs i mit arbejde med køn og alder.

\section{HISTORIK OM KØN OG SUNDHED}

Historisk set har tendenserne skiftet frem og tilbage med hensyn til interessen for kønsforskelle relateret til sundhed. Ifølge den danske kvindehistoriker Bente Rosenbeck (1992), har mandlige læger siden etableringen af moderne lægevidenskab i slutningen af 1800-tallet bidraget til at biologisere og sygeliggøre kvindekroppen ud fra en mandlig norm og et androcentrisk blik. Først med Kvinde kend din krop og rødstrømpebevægelsen kom der i 1970'erne skub i den offentlige interesse for kvinders sundhed og sygdom. I denne periode handlede al offentlig omtale af kønnet sundhed primært om kvinder.

Men da det mandlige køn blev 'opdaget' i sundhedsmæssig forstand som et kønnet fænomen, etableredes i USA i 1994 en national Men's Health Week, hvor intentionen var at påkalde opmærksomhed på mænds særlige sundhedsproblemer. Ideen blev internationaliseret i 2002, hvor denne uge med særligt fokus på mænds sundhed kom til Danmark i 2003, lanceret af Selskab for Mands Sundhed, som er et mindre selskab, der for egne midler gør et stort arbejde for at udbrede budskaber om mænd og sundhed. I USA blev der også indført en national Women's Health Week i 1999, som ikke findes i Danmark. I det hele taget har der i de senere år været ret stille om kvinders sundhed, navnlig aldre kvinders sundhed.

\section{KøN I OFFENTLIG SUNDHEDSFORMIDLING}

I rapporten "Kønsforskelle i sygdom og sundhed" blev diverse sundhedsmæssige kønsforskelle af biologisk og miljømæssig art gennemgået med en ligelig fremhævning af fordele og ulemper for begge køn i forhold til sygdomsforekomst, årsager og behandling (Kruse og Helweg-Larsen 2004). I rapporten blev det også konstateret, at:

Kønsrollernes og andre sociale faktorers betydning for sygelighed og reaktioner på sygdomssymptomer er kun delvist afklaret. Der er fortsat brug for altid at inddrage kønnet i presentation af befolkningens sundhedsproblemer og $\mathrm{i}$ analyser af årsagerne hertil (Ibid. 12)

Siden da er der ikke sket så meget med hensyn til forskning i kønsforskelle (Petersson 2009) og det ser ud til, at det offentlige SundhedsDanmark i en periode har vægtet mænds sundhed højere end kvinders. Dette kønsskæve fokus kan eksempelvis ses i den offentlige sundhedsformidling i Danmark. Går man ind på Sundhedsstyrelsens hjemmeside finder man en alfabetisk liste over emneord. Under $M$ finder man et særskilt link benævnt "mænds sundhed", hvor der står:

Mænd i alle aldre har en højere dødelighed end kvinder. Danske mænd har en middellevetid på 76,3 år, mens kvinder i gennemsnit kan forvente at leve 80,7 år. Rygning, alkoholoverforbrug, trafikulykker og arbejdsbetingede lidelser er de største kendte enkeltfaktorer, der bidrager til kønsforskellen i middellevetid, men det forklarer langt fra hele forskellen.

(www.sst.dk/ Sundhed og forebyggelse/MaendsSundhed.aspx). 
Der henvises til andre rapporter med relation til mænds sundhed i 2010 og 2011. Går man derimod tilbage til den alfabetiske liste og søger under ' $\mathrm{K}$ ' (for Kvinde), finder man intet om kvinders sundhed.

Andre eksempler er, at mange kommuner i de senere år har haft adskillige initiativer som "mænd og motion" og "mænd og madlavning", fordi det viser sig at være sværere at tiltrække ældre mænd til forebyggelsesinitiativer, og det kræver en særlig indsats at fă dem til at komme og deltage (Rohde 2009). Sammenlignelige initiativer for kvinder findes der få af. I Dansk Gerontologisk Selskab viede man desuden det årlige møde i 2010 om forskning og udvikling til temaet Manddom og alderdom med seks gode plenumoplrg om viden og udviklingsprojekter fra det ganske land. Næste år inviterede man så oplægsholdere, der kunne sige noget om xldre kvinder. Det lykkedes kun at finde to.

Et sidste eksempel: I 2008 blev der etableret et nyt videnskabeligt tidsskrift, The Aging Male. Det blev straks indkøbt af Det Kongelige Bibliotek til udlån. Et andet tilsvarende tidsskrift, Journal of Women and Aging, er udkommet siden 1989 og kunne derimod ikke findes på bibliotekets hylder i 2009, før jeg selv henvendte mig og bad om, at det blev indkøbt.

Disse eksempler kan hver især virke små og tilfældige, men sammenholdt giver de indtryk af, at der er behov for kritisk refleksion omkring kønsskævheder i systemet.

\section{KLINISK FORSKNING OG KØNSFORSKELLE}

Epidemiologerne studerer kønsforskelle, men erkender også, at der findes for få studier af årsager til kønsforskelle (Van Oyen et al. 2010). Inden for klinisk forskning af menneskets krop og biologi anbefales det, at forsøg inkluderer forskelle i alder, køn og race for at kunne vurdere betydningen af $\mathrm{fx}$ et lægemiddels virkning (Graugaard 2007, Lægemiddelindustriforeningen 2007). Ved det amerikanske Institute of Medicine har forskere dokumenteret kropslige kønsforskelle i sundhed gennem hele livsløbet, (IOM 200la), og det pointeres derfor, hvor vigtigt det er at tage højde for disse forskelle:

Also of increasing importance in the design and conduct of basic, applied, and clinical research in understanding the biological basis of sex and gender differences and their determinants. Research in these areas is of particular interest due to a renewed focus on women's health issues and to the historical lack of research on conditions that are more prevalent in women or that manifest themselves differently in males and females (IOM 2001b: 74).

I Danmark synes den biologiske og kliniske sundhedsforskning dog stadig at have et androcentrisk udgangspunkt. Den menneskelige krop, i objektivt ental, repræsenteres og universaliseres som 'manden'. Et eksempel på dette kan gives fra Københavns Universitet, hvor der siden 2010 er foregået et interventionsprojekt kaldet FINE om overvægt og fysisk træning $\mathrm{i}$ et sundhedsfremmeperspektiv. Til brug for laboratorieundersøgelser af dosis-virknings effekter af fysisk aktivitet anvendes udelukkende "raske overvægtige og inaktive mænd" i alderen 20-40 år som forsøgspersoner. ${ }^{3}$

Spørger man, hvorfor sådanne kliniske forsøg bliver baseret på ét køn i én alder begrundes dette med, at andre køn (kvindekønnet) med sin månedlige cyklus kan virke forstyrrende på forsøgets resultater, ligesom forskerne ikke vil risikere at skade en eventuel graviditet. ${ }^{4}$

Konsekvensen bliver naturligvis en tilsvarende risiko for, at de fundne resultater, for eksempel på dosis-virkning i forhold til vægttab eller en bestemt mængde medicinering, ikke passer til de anderledes kroppe, som kvinder åbenbart har, sammenlignet med mænd. Ikke desto mindre anvendes resultaterne af denne slags forskning på tilsyneladende homogene kroppe som ud- 
gangspunkt for behandling, ikke alene af et andet køn, men også af en anden alder, eksempelvis ældre mennesker, der ofte har mere komplicerede, sammensatte sygdomsbilleder end yngre, samtidig med at kroppens fysiologi også xndres med alderen (Vass og Hendriksen 2007). Hos ældre mennesker er der stor grad af polyfarmacy; brugen af mange samtidige lægemidler, hvis virkninger kan påvirke hinanden, uden at konsekvenserne af dette er kendt (Ibid.). Dette er især risikabelt hos ældre kvinder, der tager mere medicin end ældre mænd og samtidig har kroppe, der både aldersmæssigt og kønsmæssigt afviger fra forsøgspersoner som de ovennævnte.

Lægerne Karin Garde og Birgit Petersson har advaret mod en stigende kønsneutralisering inden for sundhedsområdet (Hagerup 2011). Der findes stort set ikke litteratur om farmakologiske forsøg, som tager højde for eller kan forklare kønsforskelle, skønt det ifølge professor i klinisk farmakologi Kim Brøsen, er kendt, at kvinder i forhold til mænd har mindre af enzymet CYP1A2, der bruges til at nedbryde forskellige stoffer, herunder visse lægemidler, i leveren (Brøsen 2007). Brøsen udtalte derfor til fagbladet Pharma:

Det er nærmest politisk ukorrekt at tale om, at der er biologiske forskelle på de to køn. Af samme grund er vores nuværende viden om lægemidlers omsætning hos henholdsvis mænd og kvinder meget begrænset. Jeg har endnu aldrig set et forsøg planlagt med henblik på at afprøve en kønsfor-skel. Her taler jeg om et velplanlagt og tilrettelagt videnskabeligt forsøg med det formål at afklare, om mænd og kvinder reagerer forskelligt på et eller flere lægemidler (Hagerup 2011).

Kvinder indberetter 30 procent flere bivirkninger ved medicin end mænd, men pga. manglende forskning på området ved man ikke, om kvinder i højere grad indrapporterer bivirkninger på grund af fysiologiske eller kulturelle forskelle (Brøsen 2007).
KøN, ALDER OG SUNDHEDSSTATISTIK

Kvinder lever længere og er mere syge end mænd, selv om de ifølge Sundhedsstyrelsens rapport Aldrebefolkningens sundhedstilstand fra 2010 lever sundere end mænd. Derfor bruger de også mere medicin. $60 \%$ danskere over 75 år - hvoraf de fleste er kvinder - indtager mere end tre receptpligtige medicinpræparater dagligt. Alle undersøgelser af befolkningens sundhedstilstand viser, at mens mændene dør før kvinderne, så lider kvinderne mere end mændene - og i længere tid (Schei og Bakketeig 2007). I rapporten om xldrebefolkningens sundhedstilstand fremgår det også, at danske mænd og kvinder over 60 år i 2005 kunne forvente at leve med god funktionsevne $\mathrm{i}$ henholdsvis 15,5 år for mænd og 15,6 år for kvinder; altså det samme. Derefter har mændene statistisk set 4,3 år tilbage med funktionsbegrænsning, for kvinder er tallet 7,4 år. Kvinderne er langt mere syge, og de lider oftere af sygdomme, som er svære at behandle, fx slidgigt, inkontinens, astma og allergi, grå stær, knogleskørhed, migræne og psykiske lidelser. Når mænd og kvinder over 65 år er blevet spurgt, om de har haft smerter eller ubehag inden for de sidste 14 dage, svarer kvinderne i stort tal over mændene "ja”, især til smerter i knogler, led, ryg og lænd, samt hovedpine og træthed.

Også indtægt og dermed arbejdsmarkedstilknytning har betydning for sundhed. Kvinders tilknytning til arbejdsmarkedet er ringere end mænds, og i 2011 var de 15,6 \% dårligere lønnet (Danmarks Statistik 2011). Tidligere har kvinder været dårligere uddannet end mænd, hvilket blandt andet kunne forklare lønforskellen, men med hensyn til uddannelsesniveau haler kvinder nu ind på mænd, og derfor kan uddannelsesniveau ikke længere forklare lønforskellen (Deding og Wong 2004; Sjørup 2009). For ældre kvinders vedkommende gælder det ulige uddannelsesniveau dog stadig, og derfor kan tallene for udsagn om dårligt subjektivt helbred, som især repræsenteres 
af kvinder og kortuddannede, i dobbelt forstand være kvindekønnede. Lille løn og lille kontrol over arbejdsforhold angives at være stressfremkaldende faktorer (Mæland og Haughland 2007), og blandt erhvervsaktive mænd og kvinder, som har været syge eller skadede, kommer langt færre kvinder end mænd tilbage til arbejdsmarkedet, dvs. de mister deres indtægt og økonomiske uafhængighed (Sundhedsstyrelsen 2011).

Danmark har en lavere tilbagetrækningsalder for kvinder end den gennemsnitlige alder for kvinder $\mathrm{i}$ andre OECD-lande, nemlig 61,4 år i 2009 mod 62,3 i gennemsnits-OECD (Goul Andersen og Jensen 2011; OECD 2011). 50,9\% af de danske kvinder $\mathrm{i}$ aldersgruppen 55-64-årige var i beskæftigelse i 2009. I Norge, derimod, var tallet 64,6 \% mens det i Sverige var 66,8 \% og Island 76,4 \% (Ibid.). Danske kvinder fra 65 år og opad er desuden (ligesom i resten af verden) i gennemsnit langt fattigere end mænd i tilsvarende alder. I gruppen af 65+- årige mænd er der 6,5\%, som lever med en personlig bruttoindkomst på 099.000 kroner årligt, mens der blandt kvinder er $17,5 \%$ som må leve for under 100.000 kroner om året. I den anden ende af skalaen er der 5,6\% af mændene, som har over 500.000 kroner til rådighed, mens dette gør sig gældende for blot 1,2\% af de xldre kvinder (Sundhedsstyrelsen 2010). Det er i højere grad kvinder og ufaglærte, især ældre kvinder, som er på overførselsindkomster, førtidspension og efterløn (Danmarks Statistik 2011; AE 2011). Socioøkonomiske faktorer har dokumenteret betydning for sygdom (Sundhedsstyrelsen 2011), hvilket også gælder relationen mellem socioøkonomi, køn og alder.

Betragter man sygdom og sundhed i et livsløbsperspektiv, er det relevant at huske på ældre kvinders dobbeltfunktion som både udearbejdende og primære omsorgsgivere i familielivet (Blaakilde 2011). Danske kvinder var blandt de første i verden, der gik på arbejdsmarkedet i 1970erne, og det er også dem, som har den korteste levetid i
Norden (Bakketeig og Schei 2007: 50). Dette kunne skyldes, at dobbeltarbejde mellem familie og arbejdsmarkedet er en klar helbredsmæssig risikofaktor for kvinder (Daatland et al. 2010). I Sverige viste et etnologisk studie, at visse kommuner havde indrettet deres socialpolitik således, at det accepteredes, at netop kvinder over 60 år havde op til $50 \%$ sygefravær, fordi der var en udbredt forståelse for belastningen ved deres omsorgsmæssige rolle i det nære miljø, samtidig med deres livslange erhvervsdeltagelse (Frykman og Hansen 2009).

Den nylige nedlæggelse af efterlønnen som en tidlig pensionsform i Danmark har især ramt ældre kvinder, ufaglærte og personer i udkantområder (AE 2011; Goul Andersen og Jensen 2011). Efterlønnen har nok bidraget til det høje antal af kvinder, som ikke er på arbejdsmarkedet, men nedlæggelsen af samme kan også ses som et eksempel på fravær af en dansk, samfundsmæssig forståelse for mange kvinders livslange helbredsrisiko pga. dobbeltarbejde.

\section{DEN OFFICIELLE DANSKE \\ SUNDHEDSPOLITIK}

I 2011 udkom rapporten Ulighed $i$ sundhed fra Sundhedsstyrelsen. Forfatterne indleder arbejdet med en præterition om, at ulighed er et meget komplekst fænomen, som er svært at måle, og at der derfor hovedsagelig fokuseres på det, der benævnes "den sociale inddeling”, og som primært fortolkes som befolkningens uddannelsesniveau.

Selv om forfatterne flere steder i analyserne viser, at indtægt faktisk har størst betydning for sundhed og funktionsevne, kobles netop indtægtsparameteret kun få steder sammen med parametre som køn, etnicitet og alder. Dette betyder, at kønsdimensionen har en tendens til at blive overset i rapporten, da kvinder, og især ældre kvinder, i højere grad end mænd har lavere indtægter og sårbart helbred. Rapporten kommer vidt omkring, men skønt hensigten er at give indsigt $\mathrm{i}$ ulighedsfaktorer $\mathrm{i}$ 
sundhed, kunne det have været interessant med mere viden specielt om køn, alder og etnicitet - faktorer, som ikke nævnes i sammenfatningen.

Det angives, at i de tidligere store danske Sundheds- og Sygeligheds- undersøgelser finder man, at hjertekar-sygdomme står for godt $20 \%$ og kræft for godt $10 \%$ af uligheden i restlevetid mellem uddannelsesgrupper. Muskel-skelet-besvær, som er en lidelsesgruppe, der rammer kvinder i langt højere grad end mænd, står for over $70 \%$ af uligheden, når den måles som år med langvarig begrænsende sygdom. Rapportens forfattere vælger dog i stedet en anden metodisk tilgang, den såkaldte DALY. DALY er en WHO-beregningsmodel, som ikke rummer denne kønsskævhed, fordi den ikke medtager muskel-skeletsygdomme. I stedet optræder 10 andre udvalgte sygdomme, fordi de, med Sundhedsstyrelsens ord:

... bidrager mest til ulighed efter uddannelse i sygdomsbyrde. Sammenlagt står de for $85 \%$ af uligheden. Bag de enkelte tal i denne tabel findes en lang række antagelser og usikkerheder, men der kan drages to konklusioner: Den ene er, at de ti sygdomme som her er nævnt, er dem, der dominerer billedet, selvom rækkefølgen kan være noget usikker. Den anden konklusion er, at det stort set er de samme sygdomme, der (...) dominerer sygdomsbyrden i hele befolkningen...

(Sundhedsstyrelsen 2011: 37).

Ved at ignorere muskel-skeletsygdomme i sin beskrivelse af ulighed i den danske sundhed kommer Sundhedsstyrelsen dermed til at eliminere en reel og stor sygdomsbyrde, som har en stærk kvindekønnet slagside. Hovedrolleindehaveren i rapporten om ulighed i sundhed er dog hverken sundhed eller sygdom, men levetid. Sundhed defineres faktisk som levetid hele rapporten igennem, for eksempel i indledningen, hvor problemet beskrives:

Dødeligheden er ikke bare høj, der er også en markant ulighed i dødelighed (...) [hvilket] har været medvirkende til, at Sundhedsstyrelsen og Københavns Universitet har gennemført dette udredningsarbejde for at komme tættere på, hvad der i Danmark kan gøres for at mindske ulighed i sundhed. (Ibid:5).

Sygdommen er så at sige dødeligheden.

\section{KØNSPOLITISK SUNDHED}

Det er ingen overraskelse, at sundhedsmyndigheder og forskere har fokuseret snævert på dødelighed som et sygdomstegn, for det indgik som det eneste politiske mål i den borgerlige regerings Sundhedspakke fra 2009, at middellevetiden i Danmark skulle forlænges med tre år frem til 2020. Der står ikke 'køn' på denne middellevetidsinteresse, men det er klart, at når 'sygdommen' defineres så snævert, og når denne 'sygdom’ er så kønsspecifikt ulige, som den er, peger den store sundhedspolitiske opmærksomhed også snævert på danske mænds helbred - på bekostning af de sygdomme, som kvinder i højere grad lider af. Som politisk mål er netop det danske sundhedsmål dog helt i tråd med politisk ideologi i et konkurrencebaseret samfund. Det er let at måle levetid, og det er derfor også let at anvende levetidsbarometer i den evindelige konkurrence med omverden om at være 'verdens bedste' land.

Men dette mål svarer ikke til WHOs oprindelige sundhedsmål, som Danmark plejer at følge, nemlig at målet er at føje år til livet og liv til årene. Og det svarer heller ikke til EUs målsætninger, som - i anerkendelse af ældre kvinders større risiko for fattigdom, sygdom og diskrimination - påkalder medlemslandene flere kønsrelaterede tiltag, som for eksempel at anerkende kønsdimensionen $\mathrm{i}$ sundhed og indføre kønsmainstreaming i de nationale sundhedspolitikker (EU Committee 2011). Det er på tide, at Danmark følger efter de andre lande på det kønspolitiske område. 


\section{Noter}

1. www.sst.dk. Lokaliseret sommeren 2012.

2. www.sundmand.dk. Lokaliseret sommeren 2012.

3. http://fine.ku.dk/forsoegspersoner. Lokaliseret 5.6.2012.

4. Personlig kommunikation med dr.med. Kaare Christensen, professor og overlæge ved Syddansk Universitet.

\section{LITTERATUR}

- AE Arbejderbevægelsens Erhvervsråd (2011): Efterlon. Hvem går på efterlon som 60 eller 61 àrige? 13. maj 2011.

- Bakketeig, Leiv S. \& Schei, Berit (2007): Vil kvinner altid leve længere enn menn? i: Berit Schei \& Leiv S. Bakketeig (red.): Kvinner lider-menn dør. Folkehelse i et kjønnsperspektiv. Gyldendal Norsk Forlag, Oslo: 50-67.

- Blaakilde, Anne Leonora (2011): Bedstemorsnak. Et kulturanalytisk studie af eldre kvinders liv $i$ dansk familiekultur $i$ det 20. århundrede. Ph.d.-afhandling, Københavns Universitet.

- Brøsen, Kim (2007): Kønsforskelle i farmakologien, i: Ugeskrift for Leger 2007/169/25: 24082411 .

. Christensen, Kaare \& Juel, Knud (2009): Helbred og dødelighed hos mænd og kvinder - et paradoks, i: Gerontologi 2009/3: 14-17.

- Daatland, Svein Olav; Ceenstra, Marijke \& Lima, Ivar A. (2010): Norwegean sandwiches. On the prevalence and consequences of family and work role squeezes over the life course, i: European Journal of Ageing 2010/7/4: 271-81.

- Danmarks Statistik (2011): Kvinder og Mand. Temapubl. 2011:7.

- Deding, Mette \& Wong, K. (2004): Mand og Kvinders lon-an analyse af longabet 1997-2001. Socialforskningsinstituttet 04: 10.

- EU Committee (2011): DRAFT report on the situation of women approaching retirement age (2011/2091 (INI)) Committee on Women s Rights and Gender Equality. Rapporteur: Edit Bauer.

- Frykman, Jonas \& Hansen, Kjell (2009): I obälsans tid. Sjukskrivningar och kulturmönster $i$ det samtida Sverige. Carlssons, Stockholm.

- Goul Andersen, Jørgen \& Jensen, Per H. (red.) (2011): Tilbagetrakning fra arbejdsmarkedet - àrsager og effekter. Frydenlund Academic, Frederiksberg.
- Graugaard, Christian (2007): Kønnet i medicinen - et mørkeland. Videnskab og Praksis - leder, i: Ugeskrift for Lager 169/25: 2393.

- IOM (2001a): Exploring the Biological Contributions to Human Health: Does Sex Matter? Consensus Report, April 24, 2001. Institute of Medicine, Washington, D.C. National Academy of Sciences. Lokaliseret 1.9.2012 på: www.iom.edu/Reports/2001/Exploring-the-Biological-Contributions-to-Human-Health-Does-Sex-Matter.aspx

- IOM (2001b): Informing the Future. Critical Issues in Health. Institute of Medicine, Washington, D.C. National Academy of Sciences. Lokaliseret 1.9.2012 på: Informing the Future: Critical Issues in Health http://www.nap.edu/catalog/10059.html - Kruse, Marie \& Helweg-Larsen, Karin (2004): Konsforskelle $i$ sygdom og sundhed. En afdakning af sygdomsomraider hvor kvinder og mand skiller sig serligt ud, af kønsforskelle i risikofaktorer for sygdom og $i$ reaktionen på sygdomssymptomer. Statens Institut for Folkesundhed og Ministeriet for Ligestilling.

- Lxgemiddelindustriforeningen (2007): Patienten $i$ kliniske lagemiddelforsøg.

- Mrland, John Gunnar \& Haughland, Siren (2007): Sykelighet blant kvinner oc menn i Norge, i : Berit Schei og Leiv S. Bakketeig (red.): Kvinner lider - menn dør. Folkehelse $i$ et kjønnsperspektiv. Gyldendal Norsk Forlag, Oslo: 69-87.

- OECD (2011): Pensions at a Glance. Retirementincome systems in OECD and G20 countries.

- Petersson, Birgit (2009): Den nødvendige viden om køn og kønsforskelle, i: Ugeskrift for Lager 2009/49/171: 3587 .

- Hagerup, Annette: (2011): Kønsforskelle og medicin er et tabubelagt emne, i: Pharma, Hellerup, maj/2011.

- Rohde, Anne-Dorthe (2009): Kan gamle mænd dunke? i: Gerontologi 2009/3: 4-9.

- Rosenbeck, Bente (1992): Kroppens politik. Om køn, kultur og videnskab. MTF, København.

- Schei, Berit \& Leiv S. Bakketeig (Red.) (2007): Kvinner lider - menn dor. Folkehelse $i$ et kjønnsperspektiv. Gyldendal Norsk Forlag, Oslo.

- Sjørup, Karen (2009): Løn, kønsarbejdsdeling, foraldreskab og ligestillingspolitik. Rapport til Lønkommissionen. RUC, Institut for Samfund og Globalisering, Roskilde.

- Statens Institut for Folkesundhed (2007): Folkesundhedsrapporten, Danmark 2007.

- Sundhedsstyrelsen (2010): Aldrebefolkningens sundhedstilstand i Danmark - analyser baseret pa Sundheds- og sygelighedsundersøgelsen 2005 og udvalgte registre. 
- Sundhedsstyrelsen (2011): Ulighed i Sundhedàrsager og indsatser.

- Van Oyen, Herman; Cox, Bianca; Jagger, Carol; Cambois, Emmanuelle; Nusselder, Wilma; Gilles, Clare \& Robine, Jean-Marie (2010): Gender gaps in life expectancy and expected years with activity limitations at age 50 in the European Union: associations with macro-level structural indicators, $\mathrm{i}$ : European Journal of Ageing 2010/7: 229-237.
- Vass, Mikkel \& Hendriksen, Carsten (2007): Ældre og medicin, i: Månedsskrift for Almen Praksis 2007/6: 639 .

Anne Leonora Blaakilde, postdoc, ph.d. Center for Sund Aldring Københavns Universitet 